\title{
Discursive Analysis of Hausa Language Use in a Kannywood Film: Basaja Gidan Yari
}

\author{
Aboubakar Nana Aichatou \\ English Department, Abdou Moumouni University, Niamey, Niger Republic \\ Email:nanaaichatou7@yahoo.com
}

How to cite this paper: Aichatou, A. N. (2021). Discursive Analysis of Hausa Language Use in a Kannywood Film: Basaja Gidan Yari. Advances in Literary Study, 9, $42-52$

https://doi.org/10.4236/als.2021.92006

Received: December 27, 2020

Accepted: March 31, 2021

Published: April 2, 2021

Copyright $\odot 2021$ by author(s) and Scientific Research Publishing Inc. This work is licensed under the Creative Commons Attribution International License (CC BY 4.0).

http://creativecommons.org/licenses/by/4.0/ (c) (i) Open Access

\begin{abstract}
The paper studies Hausa films language through the analysis of communication strategies, namely figurative language (proverbs, metaphor), Code switching/Code mixing and Coded-language. The paper attempts to demonstrate how the characters' use of these devices is deliberate, conscious. It shows that proverbs are commonly used as communication strategy not only to "embellish" but also to "convey deeper meaning" (Aduku, 2018) which helps reveal character competence and proficiency in the language. It also discovers that code switching/code mixing is used purposely as a communication strategy to structure speech in film conversation. As for coded message, it reflects a change in handling matters where communication is done in a restricted secret manner through coded message. Also, the examples extracted from the Hausa Film Basaja are to show that for proper understanding of the language, the surface meaning of words is to be examined.
\end{abstract}

\section{Keywords}

Hausa Films, Discourse, Proverbs, Code Switching/Code Mixing,

Figurative Language, Coded-Language

\section{Introduction}

Language is, according to (Aduku, 2018), a "crucial and central to African dra$\mathrm{ma} / \mathrm{film}$, and is one aspect of African histrionics whose essence seems to increase in appreciation especially in video film productions". Aliyu (2014) quoting Aristotle supports that it is "the most beautiful language expressing the highest idea". On the other hand, "African drama/film is functional. It is known to create cultural re-awakening. It connects society and community by re-energising the relationship between the living, the dead, and yet unborn" (Aduku, 2018); whereas Chamo (2012) is of the view that "film discourse or what is commonly called 
'film text' is of great significance in the study of social behavior and identity." However, specialists and analysts of language and discourse examine film language from two different points of view so that "formal linguists consider the discourse as a particular unit of language above the level of sentence" while functionalists view it "as a particular focus on language use" (Schiffrin, 1994). For the purpose of this research, the functionalist view is employed.

Language serves different functions among which imparting information, as well as revealing character. The methodology used is that of Fasold (1990), who suggests that: "the study of discourse is the study of any aspect of language use" and as well as that of Brown and Yule (1983) who define the analysis of discourse as "necessarily the analysis of language in use. As such it cannot be restricted to the description of linguistic forms independent of the purposes of functions which these forms are designed to serve in human affairs." Mainly, as Crystal (1971) puts it: "it is impossible to conceive of a rational being or of a society, without employing the existence of a language..." Else, "language data are therefore sources for theorizing about society (Chamo, 2012). Schiffrin (1994) following. Fairclough (1989) suggests, "language is part of society; linguistic phenomena are social phenomena of a special sort, and social phenomena are (in part) linguistic phenomena". According to this view, language and society are intimately related, "so interwoven that the analysis of language as an independent system would be insufficient" (Chamo, 2012).

Discursive analysis may also be related to communicative practices in that "Language is used as a vehicle of characterization where every character is made to speak in a way that is appropriate to his class, status, etc" (Aliyu, 2014: p.125). Using distinct languages/codes as variations of the same language; the distinctions/differences affect how language is used, expressed and understood. Some authors argue that when we consider the social level of characterization, the place of language to distinguish between characters who belong to various social classes becomes inevitable.

As a result, we share Fasold (1990) and Gumperz (1982) assumptions that when a text is considered as a code for itself that the code varies according to areas of communication and undergoes changes according to the purposes of communication, the film text, as well, finally turns to be a specific code which reflects public discourse and it seemingly causes to change it.

A relatively new phenomenon (...), the Hausa film despite the unquestioned role of entertainment, also creates new ways of speaking of presented topics and situations (...). It is therefore for these reasons that the language of Hausa films can be considered as discourse that may be analyzed in comparison with a communicative practice accepted in traditional Hausa society (Chamo, 2012).

In fact, the data used for this research were collected from a Kannywood film: "Basaja: Gidan Yari” directed by Adam A. Zango (A well-known Nigerian film producer and actor). The film is selected tentatively to highlight the new speech 
practices with regard to code-switching/code-mixing, coded language that are identified in dialogues.

There is no doubt that the paper seeks to fill the gap with regards to Hausa discourse practices which are considered by natives as strong and important factors of their cultural identity. We align with Chamo (2012) to point out that studies on the above-mentioned remain few and far less developed. As a result, an attempt has been made to analyze the function of a Hausa film namely Basaja Gidan Yari, by taking into account the communication strategies and the significant effect it has on the characters while holding the rules of communication that do not discriminitate speakers from the society (Chamo, 2012). Thus, as said earlier, to examine the language use in Basaja, our attention will be on the use of proverbs, figurative language, code-switching, code-mixing and the interface between language and Law.

\section{Hausa Film}

Traditionally, "theatre" has been taken to refer to performance whereas "drama" has referred to the work designed for stage representation, the body of written play (Elam, 1980). Considered as either theatre or drama, then Hausa film was played by monolingual Hausa speakers except some borrowings from English in Nigeria and French in Niger Republic. But nowadays Hausa films are set in a modern environment with actors having undergone formal western education. Hence the newly introduced forms of communication in their dialogues, recognized as a manifestation of new values, which contribute to forge a new discourse.

\section{The Use of Language in the Film Basaja}

Language in drama or diction, as Aliyu (2014: p. 122) puts it, is the choice of words, phrases, sentences, structure and figurative language which combine to help create meaning. Aristotle talks of formal, middle and informal diction; he maintains even that diction in drama should be appropriately formal. Else, characters are to choose the appropriate words as "Words are not spoken in a vacuum either in drama or in real life. They always belong within a context, a situation of some kind, which produces them and which helps to give them full meaning." In film, language is represented as spoken, "It thus can be described as "performative" dependant on a performative situation which is, like the communicative situation in everyday speech, characterized by the presence of two or more speakers in the same place at the same time' (Bentley, 1979).

To examine the use of language in Basaja, we consider dialogues in their relevance and significance in determining people's identity within the Hausa society.

\section{Discursive Features in Film Language}

We align with Goddar (2006) as cited in Chamo (2012: p.137) who states that "speech practices have a cultural background and a profound 'cultural shaping'. 
We also note with Ma Newman and Gimba (1998) that in Hausa, language etiquette includes many conventional questions and responses that are part of culturally accepted communication. And «Film language reproduces only some of these aspects that can be analysed through the use of discourse theory" (Chamo 2012). Especially, linguistic evidence extracted from dialogues refers to social stratification that is manifested in language use which calls on characters to speak in a way that is appropriate to his class, status, etc.

\subsection{Figurative Language}

Dramatic language deviates from everyday language in "terms of its employment of an aesthetically functionalized language (...). Above that it may employ figurative speech to a high degree. The frequent use of images like metaphor, simile, synecdoche or metonymy characterizes the language.

\section{Proverbs/Saying}

Language in traditional African drama is expressed in the traditional speech convention of proverbs and idioms, virtually every African community employ the use of proverbs and idioms in their narrative. Proverbs and idioms in language embellish the dramatic dialogue and convey deeper meanings and essence, most times with deep philosophical meaning (Aduku, 2018).

In Hausa society, proverbs reveal users competence and proficiency. "Kamar ya/ta girma da kakarta/shi" (literally meaning as if he/she has been reared by one's grandma) talking of a young making too much skillful use of proverbial utterances in conversation. This is, because of the assumption that in Hausa society proverbs are mostly used by elders as Chamo (2012) observed; but it is generally and socially accepted that the use of proverbs reveals one's competence and proficiency in language use. So in our context 'Hausa film text/language, we consider the use of proverbs not as a device which helps make generational boundaries clear but as a communication strategy that helps reveal character. This is, because:

Based on the principles of conciseness, clarity and coherence that "shape the conception of a drama and the structuring of speech" the characters utterances are mostly restricted to the really essential things." A character in a play 'is limited in his/ her utterance to what bears or the play as a whole, keeps it moving. The character' may employ figurative speech to a high degree (......). Eric Bentley (1979).

Else, "Actors use proverbs to facilitate communication, to convey commitment, to draw attention, to be polite. But also, "to make statement indirect or less abrupt (...)". Chamo (2012).

In discourse situation, film heroes, use proverbs in different angles: so in the film Basaja for example, Sardauna used the proverb "Birds of the same features 
flock together" to make his statement indirect even though the dialogue is being conducted in a straightforward language. By using the proverb the actor invites/advises his accomplice Kairat indirectly to betray Tojodine, another actor.

In part 4 the moment they broke into Jabir's room to arrets him, the police officer, Inspector Dan Musa having purchased Jabir for long told him "Rana tara ta barawo daya lak ta mai kaya" (lit. 9 days for the thief, one single day for the owner) which can be interpreted as the inspector attempt to inform Jabir that his game is over.

Jabir, the main character says: "an dade ana ruwa kasa tana shanyewa/tsotsewa" (lit. "so much water has passed under bridge") a proverb used to make statement more indirect even when the dialogue is conducted in a straight forward language.

Another actor used proverb to express thought telling "dan halak!" (lit. Talk of the devil ...).

These proverbs used in Basaja prove proverbs as a well-settled conversation strategy in the Hausa traditional system of communication. Contrary to Chamo (2012) who observes a somehow difference of its discourse function from the regular every-day practice, we argue in the same line as Aduku (2018) that "Proverbs (...) convey deeper meanings and essence, most times with deep philosophical meaning." Therefore, they really mean the person's competence and proficiency in language use.

\subsection{Metaphor}

A figure of speech, a metaphor is an imaginative way of describing something by referring to something else which is the same in a particular way (Collins English Dictionary, Harper Collins Publishers).

"The relationship between this world and reality is metaphorical. The nature of the stage/film, therefore, the setting and the style of acting should be such as to assist the language in its creation of this metaphorical world" Aliyu (2014) quoting Agoro.

Broadly speaking, in discourse situation this kind of figurative language is used to mark indirectness.

A metaphor is also used to describe someone or something by showing their similarity with something else: addressing Sardauna, Jabir uses metaphor to express his feeling describing him this way: "Mikiya mai hangen nesa" (lit. What an eagle eye you are). "Rana ko'ina da haskenki" (lit. sun,your eyes are everywhere).

Also, characters (in this context, Jabir) use this device to praise. For example, "shege Sardauna (lit. What a genius man you are!).

Actors use metaphor to inform about a situation as Jabir does in this film; $\mathrm{He}$ tries to make Zee realize the situation she is in by sending to tell her: "Wanda ya zuba hajarsa a kasuwa mutum nawa yake jin za su kan hajar tashi" (lit. he or she 
who shows one's wares to good how many people do they think will come to buy it).

They also use it to express emotions and warn politely: "Also tell Sadi to find Rat-Head and tell her that I said: "voluntary fasting is not allowed in the month of Ramadan. If she performs voluntary one instead of the obligatory one, it will be rejected and there will be grave consequences.' Got it? Jabir is warning Khairat against the danger of being reckless as he found out that she put someone else to do the work she is likely to do.

As to Webster's New World College Dictionary, metaphor is a figure of speech containing an implied comparison, in which a word or phrase ordinarily and primarily used of one thing is applied to another. Characters, Jabir for example is found to be described in this sense: katangar karfe, gumbar dutse, kaya take sa sartse (lit: iron wall, smashed rock, tricky thorn).

These are few examples of metaphor used in Hausa film Basaja. We dare say that in film text, metaphors are also proved to be a well-settled conversation strategy in the modern Hausa system of communication that signify the user's competence and proficiency in language use.

\subsection{Code Switching/Code Mixing}

With regard to the language use in Film/drama Scholars, when commenting on the language of a film end up categorizing it either as code-switching, diglossia or borrowed words or phrases from another language.

As to code switching, Linguists in general and Sociolinguists in particular diverge on the distinction between Code Switching and Code Mixing.

Some scholars such as Muysken, P. (2000), Meyerhoff, M. (2006) and Wardhaugh (1986), do not distinguish between (code switching and code-mixing) the two concepts. In fact, they consider code switching as a form of code mixing or vice-versa. This paper uses the two concepts interchangeably

With concern film discourse we are of the same opinion as Li Wei, Sebba and Tony, Cromdal, who view Code-Switching as a means of structuring talk in conversation while Kamish Shaman studied Code-Switching as a communication device in conversation. They stated that bilinguals use CS strategies to organize, enhance and enrich their speech in order to achieve their communication objectives in Nana (2020: p. 219).

Aliyu (2014) also stated: "Code switching occurs, as to some critics, in order to distinguish between characters that belong to various social classes". Else, every character is made to speak in a way that is appropriate to his class even though Chamo (2012) asserted that "two factors are responsible for code switching in kanywood films, emotional situation, (love/sadness) or showing of identity".

\subsubsection{Code Switching}

In film dialogues, Code switching is employed as a communicational strategy used to ease tension between the story heroes. For instance, Kairat addressed to 
$\mathrm{Z}$ (a police secret agent) who broke into her house but unfortunately came to be seen:

"Welcome to my house Zee, Zaki karaso ko in sa a karaso da ke."

Kairat continued on: "ya kamata ki san kina da dumbun laifi a kanki: kidnapping, impersonation and an attempt of stealing"

In film dialogue, situation also plays a crucial role in determining the choice of words. In the following examples, the actor speaks largely in English, and then switches code to repeat the same thing in Hausa language in order to reiterate her message, attract attention, and persuade and emphasize the contents of the message.

"Sir, I want you to get me information on who Jabir might want to see in the prison"/Ina so a nemo min information wa ye Jabir yake so ya gani a prison."

“As a policeman I don't ignore any piece of information given to me./A matsayina na dan sanda bana neglecting duk wani information da aka bani."

"Kar ka damu, your daughter is safe" (lit: don't worry).

"I like the guy." (Ina bala'in sonshi). Yaron yana da hankali. (He is very intelligent)

Therefore, it proves Gumperz and Holmes's assertion right that conversational code switching serves to not only reiterate one's message but also enhance addressees' motivation to carefully scrutinize the message presented (Nana, 2020: p. 223).

\subsubsection{Code-Mixing}

Actors use Code-Mixing to warn politely, to persuade. For example, Jabir addressing Zee: "ni yanzu ina cikin prison amma wanda zai yi taking over dina ba ki san shi ba."

Zee makes use of code-mixing to persuade her addressee to get committed or engaged. “(...) Da kofa guda ce ta fita da ba zai yi ba saboda shi ba ya taking risk" when talking to the Police commander.

Zee, while talking to Jabir also mixes code to express worrying:

"Jabir virus kenan; duk wadannan abubuwan da zaka yi ta yaya zaka yi ka fita daga Najeriya bayan ka san there is no way".

Jabir: There is always a way. Kin san ansar. The code switching used in this example serves to express one's worrying

Sardauna mixes codes to impart particular effects on Kairat trying to convince her to betray her own "employer" to flee away together whit him: "ina nufin zan yi betraying din Jabir kema ki yi betraying din Tajodine da Na Allah".

These are few instances of code-switching/code-mixing that confirm Baker's (1998) submission that "Code-Switching is rather a linguistic skill" and that of Poplack (2000) for whom "it is clear that code switching is a verbal skill(....); moreover that of Adendorff and Myers-scotton in Nana (2020: p. 223), that code switching no more serves the objectives of compensation of linguistic deficiency but has become a functionally motivated behavior.

In Basaja Hausa film we find actors used Code-Switching/Code-Mixing con- 
siderably on purpose, for various reasons. What leads us to argue in the same line as Baker and Jones (1998) that CS is "a valuable linguistic strategy" which does not happen at random. In Basaja, it is revealed as a valuable newly conversational strategy.

\subsection{Coded-Message}

While "Writing is the least frequent of the four functions of language" (Soundararaj, 2012), in film dialogues, actors happen to also make use of it as conversational strategy. It is used as a medium to preserve records even though obviously more difficult to produce than speech. "It requires hard critical thinking and creative imagination to produce a written discourse or document" Soudararaj (P167) goes on to state.

In the Hausa film Basaja, the main character Jabir goes through this medium to give instructions to his fellow the so-called Sardauna. But a secret agent broke into his hidden record house, found his secret file where he was instructing Sardauna but through coded message from his Description Board as materialized in Figure 1 as follows: Put in form of a figure where we can read on the left the name of the main character next to him thats Sardauna who should fly from Saudi Arabia to Kano. On the right, he mentioned the names of all that are concerned by the operation to take place, Sardauna might or should come across/meet that are Kamalu, Kwalba, Scissors, and Zee where he even described the very first as hard and the others as easy; the address where Sardauna is supposed to go and look for another character in a coded form that is: Cross Rivers Zango Calabar Titi. Last mentioned was the name of Dauda who has gone to fetch Sardauna from the Airport, explained what's on, where to find whoever is concerned and so.

But, when studying the language of drama, it is sometimes not the apparent meaning of the words that counts, but what they do in the context of a particular situation. As to Crow quoted in Aliyu (2004: p. 123) "a good dramatist must consider not only the "surface" meaning of the words but their overt, substantial meaning but also what they are doing in terms of the characters, their relationship and the overall action". This assertion is surely, what drives the secret agent having her eye on Jabir, do all her best to find what is behind the above-mentioned

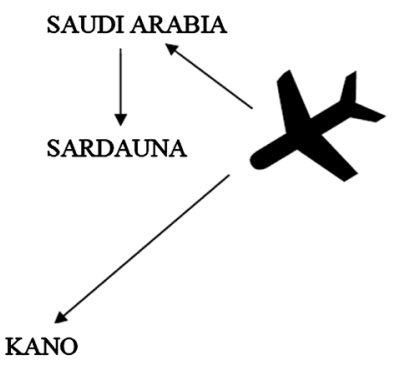

\section{ADDRESS}

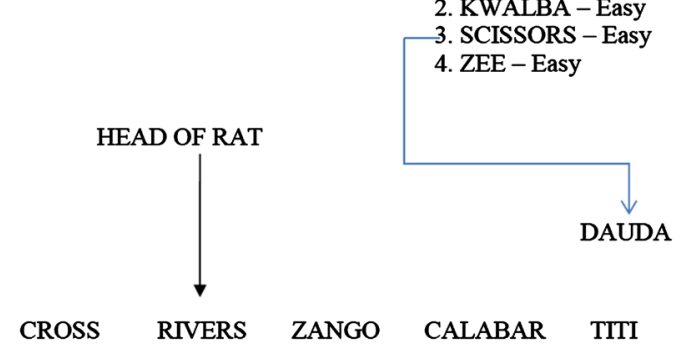

Figure 1. Coded-message from Jabir Description Board destined to Sardauna. 
coded message.

To achieve her aim that is to decipher the coded message and determine Jabir's true intent, she uses her skill, goes through a series of questioning as follow: Dauda? Sardauna? Kano? What does he mean? Cross Rivers? What does he mean? Is this their meeting point? No, this can't be. Why will they meet in Calabar? What brings Cross Rivers here? Cross Rivers?

At the end of this careful questioning/reasoning and through language analysis she succeeded in translating the meaning between the English language and Hausa language as follow: 1) Cross means Joint; 2) Rivers? Rivers? Rivers? Rivers means Koguna in Hausa; Yes, Rivers KOGUNA, so Koguna Hotel; 3) Calabar Titi? Calabar Titi? Titi means Street, Calabar Titi means Calabar Street!

Therefore, she came out with the following: Cross Rivers Zango Calabar Titi meaning: Joint at Koguna Hotel Calabar Street. Hence, the first part of the statement from Figure 1 namely: Cross Rivers Zango Calabar Titi was uncovered, elucidated. Thus, she succeeded in interpreting the meaning/the essence of one aspect of the coded message: that he, (Sardauna) should joint someone at Koguna Hotel Calabar Street (Figure 2 bellow). But who is it that he has to meet? That is the other part of the riddle she has to solve.

So joint at Koguna Hotels Calabar Street but who is he going to meet? Let us follow her again in her questioning/interpreting/deducing.

So the last question BUT WHO? WHO IS HE GOING TO MEET? Took her to the following step: always performing language analysis on the written statement she, at this point, puts emphasis on the head of the statement on the Description Board in this case Head of Rat. HEAD OF RAT? HEAD OF RAT? She

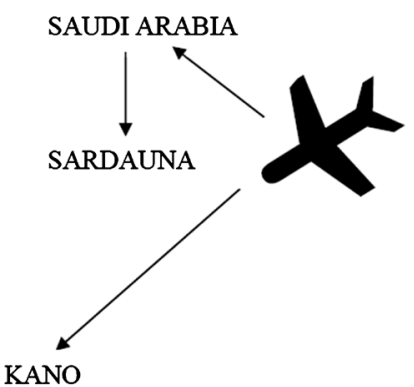

\section{ADDRESS}

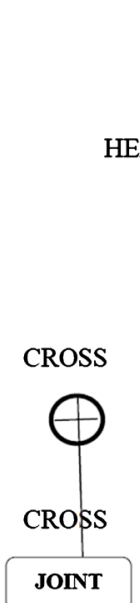

1
AD OF RAT
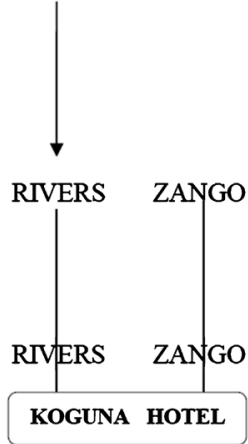

2

GAME :

1. KAMALU - Hard

2. KWALBA - Easy

3. SCISSORS - Easy

4. ZEE - Easy

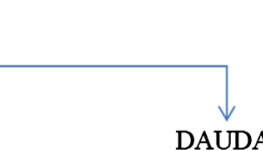

DAUDA

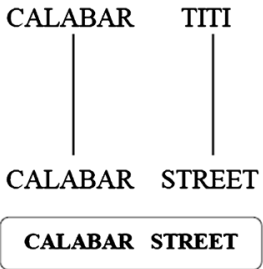

3

Calabar Street

Joint at Koguna Hotel

but who is he going to meet?

Figure 2. Zee started eliciting what is behind the code message. 


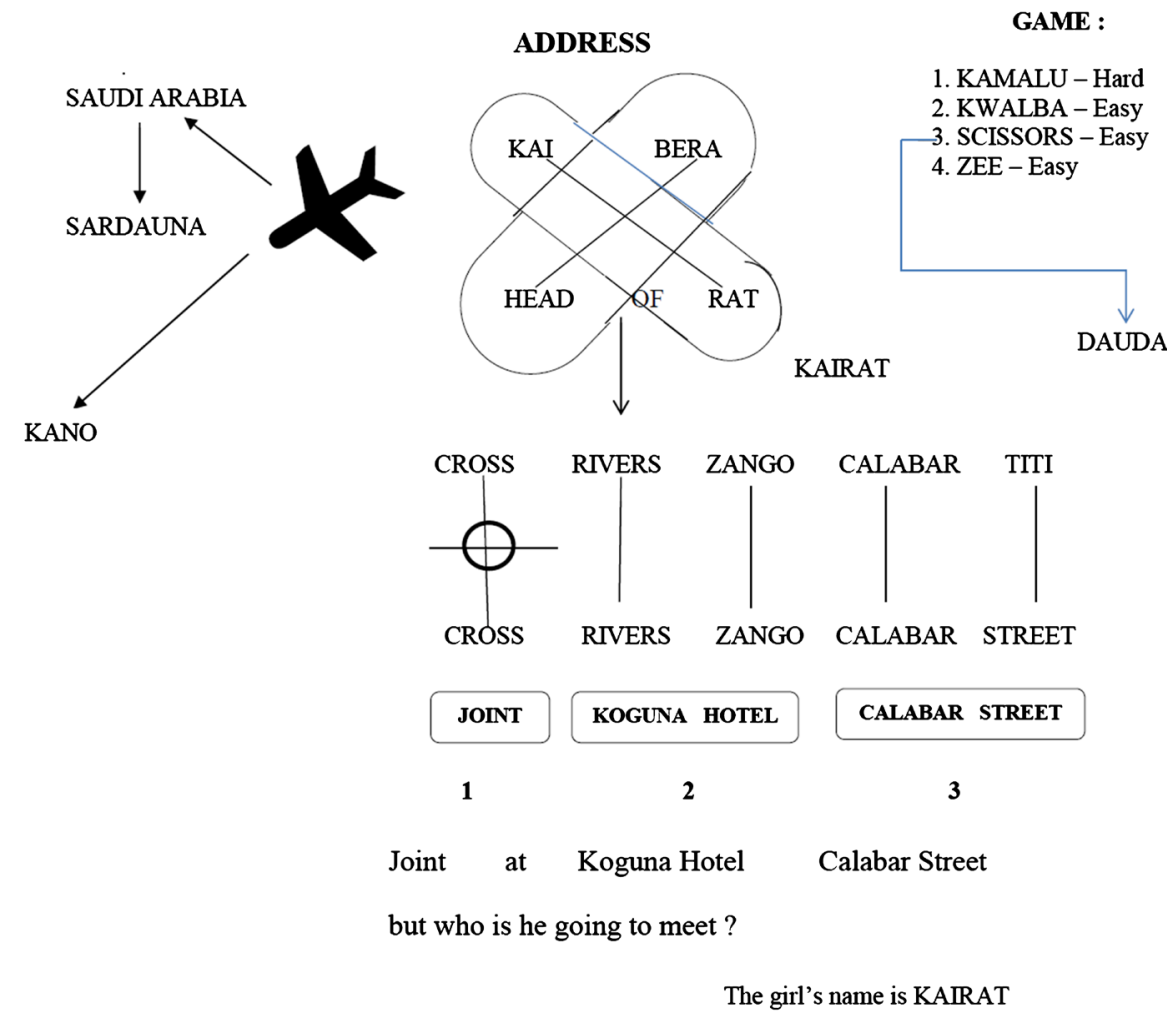

Figure 3. Zee decoded, sorted out definitely the meaning behind the coded-message.

draws the line between Kai and Rat and between Head and Bera (Figure 3): Head means Kai in Hausa she told herself. HEAD? RAT? "KAI", "BERA" "RAT", "Kai of Rat" = KAIRAT!

THE GIRL'S NAME IS KAIRAT.

At this juncture the secret agent definitely unveiled, solves the mystery behind Jabir coded message.

This example proves coded message to be a very important and interesting strategy of communication in films especially when there is interface between language and law. This strategy highlights and improves characters' proficiency as stated by the secret agent reaction once she happens to unveil, definitely, the whole mystery: "No, Jabir I am a genius, too." that producers should make use of it too often.

\section{Conclusion}

The analysis of the Hausa film text namely Basaja, shows that there are so many uses of language in its performative function/abilities to make do something, hence change something. This paper found out that language was used as communication strategies through the use of figurative language in terms of proverbs, metaphorical words and expressions, elaborate expressions. Films stories also introduce and encourage new strategies of communication namely code switching/code mixing and, the coded message or should we say the interface between language and law; all these constitute the strategically new tendencies to 
preserve the traditional way of language behaviour and the socio-cultural identification of Hausa language when especially stated that "Hausa films are both a cultural and a social phenomenon", Chamo (2012). Besides all these, language reveals character, enables us to know the role played by each character and helps us determine the tone and mood of the play.

\section{Conflicts of Interest}

The author declares no conflicts of interest regarding the publication of this paper.

\section{References}

Aduku, A. I. (2018). Elements of Traditional African Drama in Contemporary Nigerian Video-Films. https://www.Researchgate.net/publication/323936121

Aliyu, I. S. (2014). Language and Identity in Two Kannywood Films: Diction and Characterization in Gumzak's Aziza and Aminu's Malika. FAIS Journal of the Humanities, 121-134.

Baker, C., \& Jones, S. P. (1998). Encyclopedia of Bilingualism and Bilingual Education. Clevedon: Multilingual Matters.

Bentley, E. (1979). The Life of the Drama. New York: Athereun.

Brown, G., \& Yule, G. (1983). Discourse Analysis. Cambridge: Cambridge Press. https://doi.org/10.1017/CBO9780511805226

Chamo, I. Y. (2012). The Language of Hausa Films: Forging a New Discourse. International Journal of Linguistics, 4, 135-148. https://doi.org/10.5296/ijl.v4i3.2199

Crystal, D. (1971/80). Linguistics. London: Penguin Books. https://doi.org/10.1021/cen-v049n015.p080a

Elam, X. (1980). Drama in Language Teaching: A Challenge for Creative Development.

Fairclough, N. (1989). Language and Power. London: Longman.

Fasold, R. (1990). Sociolinguistics of Language. Oxford: Blackwell.

Gumperz, J. (1982). Discourse Strategies. Cambridge: Cambridge University Press. https://doi.org/10.1017/CBO9780511611834

Ma Newman, R. P., \& Maina, G. (1998). Hausa a Dace: A Guide to Functional Grammar. Bloomington, IN: Indiana University.

Meyerhoff, M. (2006). Introducing Sociolinguistics. Abingdon: Routeledge. https://doi.org/10.4324/9780203966709

Muysken, P. (2000). Bilingual Speech: A Typology of Code-Mixing. Cambridge: Cambridge University Press.

Nana A. A. (2020). Code Switching/Code Mixing in the National Assembly of Niger in International. Journal of English literature and social sciences(IJELS), 5, 217-226.

Poplack, S. (2000). The History of African American English. Oxford: Blackwell.

Schiffrin, D. (1994). Approach to Discourse. Cambridge, MA, Oxford: Blackwell.

Soundararaj, F. (2012). Basics of Communication in English Soft Skills for Listening, Speaking, Reading and Writing. Macmillan Publishers India Ltd.

Wardhaugh, R. (1986). An Introduction to Sociolinguistics. Oxford: Basil Blackwell Limited. 